\title{
Influence of parents' behavior during the meal and on overweight
} in childhood

\author{
Influência do comportamento dos pais durante a refeição e no excesso de peso na infância \\ Influencia en el comportamiento de los padres durante la comida y en el sobrepeso en la infância
}

\author{
Karen Muniz Melo \\ Ana Cláudia Pereira Cruz ${ }^{1}$ \\ Maria Fernanda Santos Figueiredo Brito ${ }^{2}$ \\ Lucinéia de Pinho ${ }^{1,2}$ \\ 1. Associação Educativa do Brasil. \\ Montes Claros, MG, Brasil. \\ 2. Universidade Estadual de Montes Claros. \\ Montes Claros, MG, Brasil.
}

\begin{abstract}
Objective: To assess the influence of parents' behavior during meals and on the overweight in childhood. Methods: Cross-sectional and analytical study, with a quantitative approach, performed with children aged between 12 and 59 months, belonging to the enrolled population of a Family Health Strategy team, in Montes Claros (MG). In order to collect data, it was used a questionnaire with sociodemographic variables related to food consumption and family influence over the eating habits. The anthropometric parameters of weight and height were assessed. We used the Student's $t$-test $(p<0.05)$ to compare the averages of the eating behavior of parents and the overweight in childhood. Results: 115 children participated. The overweight in childhood was statistically related to the behavior of parents during meals in the domains "model of sweets consumption" and "special meals". Conclusion: The family environment is associated with the formation of eating habits and the overweight in childhood.
\end{abstract}

Keywords: Feeding behavior; Child nutrition; Eating Habits, Parents.

\section{Resumo}

Objetivo: Avaliar a influência do comportamento dos pais durante a refeição e no excesso de peso na infância. Métodos: Trata-se de estudo transversal, analítico, com abordagem quantitativa, realizado com crianças de 12 a 59 meses, pertencentes à população adscrita de uma equipe da Estratégia Saúde da Família, em Montes Claros - MG. Para a coleta de dados, utilizou-se um questionário com as variáveis sociodemográficas, de consumo alimentar e a influência da família nos hábitos alimentares da criança. Os parâmetros antropométricos de peso e altura das crianças foram avaliados. Utilizou-se o teste $t$ Student $(p<0,05)$ para comparação das médias do comportamento alimentar dos pais e o excesso de peso infantil. Resultados: Participaram 115 crianças. $O$ excesso de peso infantil se manifestou estatisticamente relacionado ao comportamento dos pais durante as refeições nos domínios "modelo de consumo de guloseimas" e "refeições especiais". Conclusão: $\mathrm{O}$ ambiente familiar está associado à formação de hábitos alimentares e no excesso de peso infantil.

Palavras-chave: Comportamento alimentar; Nutrição infantil; Hábitos alimentares; Pais.

\section{REsumen}

Objetivo: Evaluar la influencia del comportamiento de los padres durante las comidas y el sobrepeso en la infancia. Métodos: Estudio transversal, analítico, con abordaje cuantitativo, efectuado con niños de 12 a 59 meses, pertenecientes a la población adscrita de un equipo de la Estrategia Salud Familiar, en Montes Claros (MG). Se utilizó un cuestionario con variables sociodemográficas sobre el consumo alimentario y la influencia de la familia en los hábitos del niño. Se evaluaron los parámetros antropométricos de peso y altura. Se utilizó la prueba $t$-Student, $(p<0,05)$ para comparar promedios del comportamiento alimentario de los padres y el sobrepeso infantil. Resultados: Participaron 115 niños. El sobrepeso en la infancia se manifestó estadísticamente relacionado con el comportamiento de los padres durante las comidas en los dominios "modelo de consumo de golosinas" y "comidas especiales". Conclusión: El ambiente familiar está asociado a la formación de hábitos alimentarios y al sobrepeso infantil.

Palabras clave: Comportamiento Alimentar; Nutrición Infantil; Hábitos Alimentares, Padres.
Corresponding author:

Lucinéia de Pinho.

E-mail: lucineiapinho@hotmail.com

Submitted on $04 / 20 / 2017$

Accepted on 08/17/2017.

DOI: 10.1590/2177-9465-EAN-2017-0102 


\section{INTRODUCTION}

In childhood, the introduction of food and the formation of taste occur and, because of that, this point constitutes a determining period in the formation of eating habits. At this stage, the food patterns that will be present in the other steps of the life cycle ${ }^{1}$ can be defined.

Food preferences are originated by a combination of genetic and environmental factors. The establishment of healthy eating habits should be stimulated early in the life of the individual. ${ }^{2}$ Parents have an important role in the formation of children's eating habits. ${ }^{3}$ Parental food choices, in relation to the quantity and quality of food, ${ }^{4,5}$ can determine the eating behavior of the children.

Children's food consumption is directly associated with their current state of health and in future years. ${ }^{6}$ Infantile feeding practices have been characterized by excessive consumption of high-energy foods, fat, salt and sugar and low consumption of fruits and vegetables. ${ }^{7}$ The consumption of these products may be related to household availability. ${ }^{8}$

This context has contributed to the increase of overweight in the child population. ${ }^{7}$ The prevalence of overweight or obese children has increased in both developed and developing countries..$^{9,10}$ In developing countries, the proportion of children with this condition increased from 8.1 per cent to 12.9 per cent for boys and from 8.4 per cent to 13.4 per cent for girls. ${ }^{10}$ In Latin America, it is estimated that 3.8 million children under the age of five are overweight or obese. ${ }^{11}$ In Brazil, a study with 4,388 children aged less than five years showed that the prevalence of overweight was $6.6 \% .^{12}$ This situation may contribute to the risk of chronic non-transmissible diseases. ${ }^{13}$

Overweight in children may be a result of the external stimuli present in their environment. ${ }^{14}$ The biological and lifestyle determinants of the child have been valued in investigations of overweight. ${ }^{14}$ However, it is essential to assess the influence of the environment, especially the family, on the eating behavior at early ages and on the child's excess weight. In this sense, this study had as objective to evaluate influence of the parents' behavior during the meal in excess weight in childhood.

\section{METHODS}

This is a cross-sectional and analytical study, with a quantitative approach, carried out in the area covered by a Family Health Strategy (FHS) team, in the municipality of Montes Claros, northern Minas Gerais.

The study population consists of children in the age range of 12 to 59 months enrolled in the FHS studied. Participation of at least 95 children was estimated, considering the following criteria for the sample calculation: total number of children under five years, $95 \%$ confidence level, sampling error of $5 \%$ and prevalence of overweight of $10 \% .^{12}$

The inclusion criteria were children who had main meals at least twice a week with the family and those who had food restrictions were excluded.
For the data collection, a questionnaire was used, considering the variables on the sociodemographic condition, food consumption and family influence on the child's eating habits. For the evaluation of economic conditions, the Brazilian Economic Classification Criterion ${ }^{15}$ was adopted. The food consumption was verified through food consumption markers for children under five years of age standardized by the Ministry of Health. ${ }^{16}$

The instrument Parent Mealtime Action Scale (PMAS), ${ }^{17}$ translated and validated into Portuguese in Brazil and called the Parent Behavior Scale during Meal, ${ }^{18}$ was applied to evaluate the behavior of parents in their children's food education. It consists of 31 issues in nine domains: daily availability of fruits and vegetables, model of consumption of treats, use of reward, many food options, fat reduction, special meals, limits for goodies, positive persuasion and insistence to eat. The frequency for behaviors was assessed in a typical family week, by the never-1, sometimes-2, or always-3 options. The answers were tabulated and to obtain the result of each of the nine domains evaluated, the average of the questions that comprised each domain was performed. To maintain consistency of analysis, questions 2 and 31 (Special Meal domain) had their values reversed. The higher the score obtained in the domain (varies between 1 and 3), the more frequent is the parents' behavior.

The anthropometric parameters of weight and height of the children were evaluated. Children under two years old were weighed in a pediatric mechanical scale (Welmy ${ }^{\circledR}$, Model $109 \mathrm{CH}$ ), with a maximum capacity of $16 \mathrm{~kg}$ and a precision of $0.01 \mathrm{~kg}$, and were measured in dorsal decubitus position with a portable stentometer (Alturexata ${ }^{\circledR}$, with an interval of $1 \mathrm{~mm}$ ). The older children were weighed on a mechanical scale (Welmy ${ }^{\circledR}$, Model $110 \mathrm{CH}$ ), with a maximum capacity of $150 \mathrm{~kg}$ and a precision of $0.1 \mathrm{~kg}$, and had the height measured in orthostatic position, using an anthropometer with the same precision (Alturexata $^{\circledR}$, with an interval of $1 \mathrm{~mm}$ ). The calculated indices for the nutritional diagnosis were: Height/Age (H/A), Weight/Age $(\mathrm{W} / \mathrm{A})$ and $\mathrm{BMI} /$ Age $(\mathrm{MMI} / \mathrm{A})$. These indexes were classified according to the World Health Organization reference standard. ${ }^{19}$

Data collection was carried out in the year 2015, between March and June, by Nutrition and Nursing academics duly trained during the child care attendance at the FHS.

Data were typed in double entry in Excel ${ }^{\circledR}$ software for inconsistency checking and were imported into Statistical Package for the Social Sciences (SPSS ${ }^{\circledR}$ ), version 19.0 for Windows for analysis. A descriptive analysis of the data was carried out by means of the absolute and relative frequency. The anthropometric variable BMI/A was dichotomized in: group 01 - No overweight (undernourished/eutrophic); group 02 - At risk or overweight (risk of overweight, overweight and obesity). All variables were submitted to the Kolmogorov-Smirnov normality test. To evaluate the difference of the means between the groups, the Student's $t$-test was used for independent samples and the accepted confidence value was $p<0.05$.

The project of this study was approved by the Research Ethics Committee (REC) No 1,057,121/2015 of the Associação 
Educativa do Brasil - SOEBRAS. All participants in the research signed a Free and Informed Consent Term.

\section{RESULTS}

Participated on the study 115 children, of which $56 \%$ were female. The average age was 35 months $( \pm 14.33)$. Most families belonged to economy class C (60\%). Regarding the level of education of the head of the family, almost half (49\%) had completed high school.

In the analysis of food consumption, it was observed that $97 \%$ of the children performed the main meals (lunch and dinner) daily with the family at home. The day before the survey, the consumption of vegetables was verified on $65.2 \%(n=75)$ of the children. Fruits were consumed by $83.5 \%(n=96)$ of the infant population. Regarding the consumption of meat, it was observed that this food was present in the meals of $85.2 \%(n=98)$ of those surveyed. With regard to eating behavior, $63.5 \%(n=73)$ were eating in the presence of television and $52.2 \%(n=60)$ at the table.

In the anthropometric analysis, it was verified that the average weight of the children was $14.67 \mathrm{~kg}( \pm 4.07)$ and the mean height of $94 \mathrm{~cm}( \pm 12 \cdot 46)$. According to the analysis of the anthropometric index, stature by age, it was observed that $93 \%$ ( $n=107$ ) of the children presented adequate height for age and in relation to the weight-for-age index, $12.2 \%(n=14)$ had a high weight. In the evaluation of $\mathrm{BMI} / \mathrm{A}$, it was observed that $12.2 \%$ ( $n=14)$ presented thinness, $51.3 \%(n=59)$ eutrophy, $17.4 \%$ $(n=20)$ risk of overweight, $10.4 \%(n=12)$ overweight and $8.7 \%$ $(n=10)$ obesity.

Descriptive measures of the Parent Behavior Scale during meals (frequency, mean and standard deviation) are presented in Table 1.

The domains of the PMAS Model of consumption of goodies $(p=0.001)$ and Special meals $(p<0.001)$ were significantly associated with the presence of excess weight (Table 2). For these domains, the means were higher in the group of overweight children.

\section{DISCUSSION}

The purpose of this study was to verify the relation between parental actions during meals and the eating habits of overweight children. The family has a determinant role during the learning process of the alimentation of the children, so that the life habits of the parents, the parenting styles and their interaction with the children are significant for the formation of the infant's eating habits. ${ }^{5,12,20,21}$

In the analysis of food consumption, almost all children had main meals daily with the family at home. This finding is important considering that the family has a set of values, beliefs, knowledge and eating habits that may constitute a protective or risk factor for health. ${ }^{22-24}$ It is important to reflect that, in the national scenario, the contemporary dietary pattern consists of industrialized and highly processed foods of high caloric value, rich in fat and sodium, which has been inserted in the home context, contributing to the obesity in the family. ${ }^{25} \mathrm{~A}$ survey carried out in Florianópolis, with adolescents, found that having lunch at school or elsewhere was a protective factor for the occurrence of overweight/obesity among public school students. ${ }^{22}$

In the present study, approximately one-third of the child population was at risk of being overweight or overweight. These data are in line with the results of a historical series on overweight in preschool children in Brazil, which showed a significant increase in the period from 1989 to $2006,{ }^{26}$ evidencing the nutritional transition in the children existent in the present day. Overweight in children is associated with multiple comorbidities, such as cardiovascular, psychosocial, orthopedic, respiratory, gastrointestinal and metabolic disorders, which may persist through adult life. Obesity in childhood leads to greater morbidity and mortality in adulthood. ${ }^{13}$

Overweight in childhood was statistically related to the behavior of the parents during the meals, in the domains "model of consumption of goodies" and "special meals". This result is in agreement with the international systematic review study that showed the relationship between parental style and child BMI. ${ }^{20}$ This picture may be due to the current phenomenon of nutritional transition experienced in society, marked by the hypercaloric diet, monotonous, with foods with a high concentration of sugars, fats and salt. ${ }^{27}$

In the domain "consumption of treats", it was observed that a relevant part of the parents of the children studied consume soft drinks and sweets daily. Unlike the adults who make their food choices, children under the age of five rely on their parents for food consumption, which is a reflection of their family environment. ${ }^{5}$ Infant and pre-school feeding in Brazil is characterized by the early consumption of sweets and soft drinks. ${ }^{28} \mathrm{~A}$ survey with 4,839 children under two years of age found a high prevalence of sugary drinks consumption, which was associated with family habits. ${ }^{29} \mathrm{~A}$ previous study that evaluated the behavior of parents in their children's food education, through the PMAS, observed higher scores in the goodies model domain associated with a child diet with higher consumption of snacks. ${ }^{18}$ This condition may favor the development of excess weight in this age group.

Excessive consumption of treats by the pediatric population favors the early development of chronic non-transmissible diseases such as diabetes mellitus and systemic arterial hypertension. ${ }^{28}$

In the field of "special meals", it was found that most parents reported that they did not consume the same foods as their child, did not offer a varied meal of foods and offered different meals from the family. This practice may reflect on a monotonous diet for children, ${ }^{28}$ which may have an impact on excess child weight. In addition, the provision of a special meal for the child may contribute to the persistent refusal of some foods. ${ }^{18}$

In this study, although the majority of the children had family meals, considered a protector for overweight, ${ }^{22}$ it was found that the food preparations were performed differently between parents and children, which was related to the presence of excess weight between the children surveyed. In responsive 
Table 1. Descriptive measures of the total score of the Parent Behavior Scale at meal times.

\begin{tabular}{|c|c|c|c|c|c|c|}
\hline Domain & Items & \multicolumn{3}{|c|}{ Frequency (\%) } & Average & S.D. \\
\hline \multirow{2}{*}{$\begin{array}{l}\text { Daily availability } \\
\text { of fruits and } \\
\text { vegetables }\end{array}$} & Do you give fruit to your child every day? & 02 & 27 & 71 & \multirow{2}{*}{2.63} & \multirow{2}{*}{0.34} \\
\hline & Do you eat greens and vegetables every day? & 01 & 18 & 81 & & \\
\hline \multirow{2}{*}{$\begin{array}{l}\text { Model of } \\
\text { consumption of } \\
\text { goodies }\end{array}$} & Do you drink soda every day? & 37 & 51 & 12 & \multirow{2}{*}{1.66} & \multirow{2}{*}{0.33} \\
\hline & Do you eat snack every day? & 51 & 45 & 03 & & \\
\hline \multirow[b]{3}{*}{ Reward Usage } & Do you make mealtime a joke or a fun time for your child? & 25 & 41 & 34 & \multirow[b]{3}{*}{1.68} & \multirow[b]{3}{*}{0.46} \\
\hline & Do you give to your child a favorite food as a reward for good behavior? & 50 & 41 & 10 & & \\
\hline & $\begin{array}{l}\text { Do you offer to your child a toy or a favorite activity as a reward for } \\
\text { good behavior? }\end{array}$ & 64 & 27 & 09 & & \\
\hline \multirow{4}{*}{ Many food options } & Do you let your child eat what he or she wants? & 42 & 38 & 20 & \multirow{4}{*}{1.67} & \multirow{4}{*}{0.42} \\
\hline & $\begin{array}{l}\text { Do you let your child put spices or sauces on the food as he or she } \\
\text { wants? }\end{array}$ & 89 & 7 & 4 & & \\
\hline & Do you let your child substitute one food for another that he/she likes? & 52 & 39 & 9 & & \\
\hline & $\begin{array}{l}\text { Do you let your child choose which foods to eat, but only among those } \\
\text { which are offered to him/her? }\end{array}$ & 26 & 29 & 45 & & \\
\hline \multirow[b]{2}{*}{ Fat Reduction } & Do you prevent your child from overeating? & 63 & 30 & 7 & \multirow[b]{2}{*}{2.19} & \multirow[b]{2}{*}{0.51} \\
\hline & $\begin{array}{l}\text { Do you make changes in your child's food to decrease the amount of } \\
\text { fat? }\end{array}$ & 13 & 18 & 69 & & \\
\hline \multirow{3}{*}{ Limit to treats } & Do you set limits on how many candies your child can eat per day? & 17 & 13 & 70 & \multirow{3}{*}{2.54} & \multirow{3}{*}{0.64} \\
\hline & Do you set limits on how much soda your child can drink per day? & 15 & 13 & 72 & & \\
\hline & Do you set limits on how much salt your child can eat per day? & 19 & 11 & 70 & & \\
\hline \multirow{4}{*}{ Positive persuasion } & Do you tell your child how much you like that food? & 16 & 12 & 72 & \multirow{4}{*}{2.57} & \multirow{4}{*}{0.48} \\
\hline & $\begin{array}{l}\text { Do you tell your child that the taste of the food will be good if he/she } \\
\text { experiences it? }\end{array}$ & 10 & 11 & 79 & & \\
\hline & Do you tell your child that your friends or siblings like that food? & 26 & 20 & 54 & & \\
\hline & $\begin{array}{l}\text { Do you tell your child that a food will make you healthy, smart, and } \\
\text { strong? }\end{array}$ & 5 & 12 & 83 & & \\
\hline & Do you insist your child to eat even if he/she says "I'm not hungry"? & 21 & 11 & 68 & & \\
\hline Insistence to eat & $\begin{array}{l}\text { Do you insist that your child eat when he or she is sleepy or not feeling } \\
\text { well? }\end{array}$ & 49 & 31 & 20 & 2.11 & 0.63 \\
\hline & Do you insist that your child eat when he or she is upset? & 30 & 25 & 45 & & \\
\hline
\end{tabular}


Table 2. Scores of the domains of the PMAS questionnaire answered by the parents according to the presence of overweight in childhood.

\begin{tabular}{lccc}
\hline Domains & No & Overweight & \\
& $\begin{array}{c}\text { Yes } \\
\text { Average (SD) }\end{array}$ & Average (SD) & p-value \\
\hline Daily availability of fruits and vegetables & $2.66(0.36)$ & $2.58(0.30)$ & 0.256 \\
\hline Model of consumption of goodies & $1.49(0.40)$ & $1.95(0.34)$ & 0.001 \\
\hline Reward Usage & $1.71(0.43)$ & $1.61(0.51)$ & 0.271 \\
\hline Many food options & $1.69(0.47)$ & $1.63(0.31)$ & 0.407 \\
\hline Fat Reduction & $2.17(0.47)$ & $2.22(0.57)$ & 0.593 \\
\hline Special Meals & $1.37(0.23)$ & $1.60(0.34)$ & 0.000 \\
\hline Limit to treats & $2.56(0.65)$ & $2.51(0.64)$ & 0.696 \\
\hline Positive persuasion & $2.59(0.48)$ & $2.56(0.49)$ & 0.755 \\
\hline Insistence to eat & $2.20(0.61)$ & $1.97(0.66)$ & 0.080 \\
\hline
\end{tabular}

eating, one aspect that should be considered is the sharing of meals. Food interaction presupposes that meals of parents and children are common. ${ }^{5}$ However, although some parents are concerned about providing healthier food for their children, they do not consume the same type of food, which may influence the child's acceptance of it.

In addition to parental actions, external factors can influence the child's ingestion of food..$^{18}$ In this study it was verified that a large part of the children had their meals watching television. The media influence on food consumption is related to the concentration of advertisements at the main meal times, which encourage the consumption of hypercaloric products and low nutritional quality. ${ }^{30}$ This practice contrasts with the guidelines for the commensality of the food guide for the Brazilian population, which recommends eating in appropriate environments without stimulating unlimited quantities of food. ${ }^{31}$

Adequate food and nutrition are basic requirements for the integrality of health care. ${ }^{26}$ Interventions for the reduction of overweight in children should focus on the family and the household $9,12,32,33$ for the promotion of positive parental eating practices, considering the role of parental modeling in children's eating behavior. ${ }^{32,33}$ Parents or guardians should be empowered about healthy eating and sensitized about the need to change the family's lifestyle. ${ }^{21}$

The strengthening of the specific actions of care in food and nutrition in Primary Care are promising, ${ }^{27}$ because it focuses on caring for the family and for developing actions in a geographically known territory, which enables knowledge and action in the family context. In this scenario, the nurse is of fundamental importance in the nutritional diagnosis of children and in the definition of strategies for the prevention of overweight and childhood obesity. ${ }^{34}$
The results of this study need to be considered in light of some limitations such as the possibility of bias of parents' responses to the reality of their behavior during the children's meals. It is not possible to establish a causal relation, due to the transversal design; moreover, the relationship of risk and protection between variables may contain biases, due to the absence of multivariate analysis. The data cannot be generalized because it was performed in a sole family health team.

\section{CONCLUSION}

Parents' behavior during the meal may have influenced their children's body mass index. Overweight in children was associated with the behavior of parents for the consumption of treats and the provision of special meals. It is expected that the results of this study contribute to the design of effective public policies for the prevention of childhood obesity, considering among the determining factors, the family context. In this sense, the strategies should contemplate the influence of the family on children's eating habits. It is suggested that new studies with longitudinal design be performed to evaluate the causal relationship between parenting and BMI of children, as well as the analysis of family functionality in the risk of childhood overweight and obesity.

\section{REFERENCES}

1. Beauchamp GK, Mennella JA. Early flavor learning and its impact on later feeding behavior. J Pediatr Gastroenterol Nutr. 2009;48 Suppl 1:S25-30.

2. Madruga SW, Araujo CLP, Bertoldi AD, Neutzling MB. Manutenção dos padrões alimentares da infância à adolescência. Rev Saúde Pública. 2012;46(2):376-86. 
3. Baek YJ, Paik HJ, Shim JE. Association between family structure and food group intake in children. Nut Res Pract. 2014;8(4):463-8.

4. Scaglioni S, Arrizza C, Vecchi F, Tedeschi S. Determinants of children's eating behavior. Am J Clin Nutr. 2011;94(6 Suppl):2006S-2011S.

5. Silva GA, Costa KA, Giugliani ER. Infant feeding: beyond the nutritional aspects. J Pediatr (Rio J). 2016;92(3 Suppl 1):S2-7.

6. Rodrigues VM, Fiates GMR. Hábitos alimentares e comportamento de consumo infantil: influência da renda familiar e do hábito de assistir à televisão. Rev Nutr. 2012;25(3):353-62.

7. Alves MN, Muniz LC, Vieira MFA. Consumo alimentar entre crianças brasileiras de dois a cinco anos de idade: Pesquisa Nacional de Demografia e Saúde (PNDS), 2006. Ciênc Saúde Coletiva. 2013;18(11):3369-77.

8. Chaffee BW. Fatores nos primeiros anos de vida que influenciam o consumo de frutas e verduras entre crianças. J Pediatr (Rio J). 2014;90(5):437-9.

9. Lobstein T, Jackson-Leach R, Moodie ML, Hall KD, Gortmaker SL, Swinburn BA, et al. Child and adolescent obesity: part of a bigger picture. Lancet. 2015;385(9986):2510-20.

10. Ng M, Fleming T, Robinson M, Thomson B, Graetz N, Margono C, et al. Global, regional, and national prevalence of overweight and obesity in children and adults during 1980-2013: a systematic analysis for the Global Burden of Disease Study 2013. Lancet. 2014;384(9945):766-81.

11. Rivera JA, de Cossío TG, Pedraza LS, Aburto TC, Sánchez TG, Martorell R. Childhood and adolescent overweight and obesity in Latin America: a systematic review. Lancet Diabetes Endocrinol. 2014;2(4):321-32.

12. Meller FO, Araújo CLP, Madruga SW. Fatores associados ao excesso de peso em crianças brasileiras menores de cinco anos. Ciênc Saúde Coletiva. 2014;19(3):943-55.

13. Neef M, Weise S, Adler M, Sergeyev E, Dittrich K, Körner A, et al. Health impact in children and adolescents. Best Pract Res Clin Endocrinol Metab. 2013;27(2):229-38.

14. Passos DR, Gigante DP, Maciel FV, Matijasevich A. Comportamento alimentar infantil: comparação entre crianças sem e com excesso de peso em uma escola do município de Pelotas, RS. Rev Paul Pediatr 2015;33(1):42-9.

15. Associação Brasileira de Empresas de Pesquisa (ABEP). Critério de classificação econômica Brasil. São Paulo: ABEP [Internet]. 2010; [cited 2015 Oct 15]. Available from: http://www.abep.org/criterio-brasil

16. Ministério da Saúde (BR). Secretaria de Atenção à Saúde. Departamento de Atenção Básica. Protocolos do Sistema de Vigilância Alimentar e Nutricional - SISVAN na assistência à saúde. Brasília: Ministério da Saúde [Internet]. 2008; [cited 2017 Jan 17]; 64 p. Available from: http://189.28.128.100/nutricao/docs/geral/protocolo_sisvan.pdf

17. Hendy HM, Williams KE, Camise TS, Eckman N, Hedemann A. The Parent Mealtime Action Scale (PMAS). Development and association with children's diet and weight. Appetite. 2009;52(2):328-39.

18. Petty ML, Escrivão MA, Souza AA. Preliminary validation of the Parent Mealtime Action Scale and its association with food intake in children from São Paulo, Brazil. Appetite. 2013;62:166-72.

19. Ministério da Saúde (BR). Secretaria de Atenção à Saúde. Departamento de Atenção Básica. Orientações para a coleta e análise de dados antropométricos em serviços de saúde: Norma Técnica do Sistema de Vigilância Alimentar e Nutricional - SISVAN. Brasília: Ministério da Saúde [Internet].2011; [cited 2017 Jan 17]; 76 p.
Available from: http://189.28.128.100/dab/docs/portaldab/publicacoes/ orientacoes_coleta_analise_dados_antropometricos.pdf

20. Shloim N, Edelson LR, Martin N, Hetherington MM. Parenting Styles, Feeding Styles, Feeding Practices, and Weight Status in 4-12 YearOld Children: A Systematic Review of the Literature. Front Psychol. 2015;6:1849.

21. Gerards SM, Kremers SP. The Role of Food Parenting Skills and the Home Food Environment in Children's Weight Gain and Obesity. Curr Obes Rep. 2015;4(1):30-6.

22. D'Avila GL, Müller RL, Gonsalez PS, Vasconcelos FAG. Associação entre estado nutricional da mãe e a frequência, local e companhia durante as refeições com o sobrepeso/obesidade de adolescentes da cidade de Florianópolis, Brasil. Rev Bras Saude Mater Infant. 2015;15(3):289-99.

23. Coelho LC, Asakura L, Sachs A, Erbert I, Novaes CRL, Gimeno SGA Sistema de Vigilância alimentar e Nutricional/SISVAN: conhecendo as práticas alimentares de crianças menores de 24 meses. Ciênc Saúde Coletiva. 2015;20(3):727-38.

24. Kneipp C, Habitzreuter F, Mezadri T, Höfelmann DA. Excesso de peso e variáveis associadas em escolares de Itajaí, Santa Catarina, Brasil. Ciênc Saúde Coletiva. 2015;20(8):2411-22.

25. Jaime PC, Prado RRD, Malta DC. Family influence on the consumption of sugary drinks by children under two years old. Rev Saúde Pública. 2017;51(Suppl 1):13s.

26. Instituto Brasileiro de Geografia e Estatística (BR). Coordenação de Trabalho e Rendimento. Pesquisa de orçamentos familiares 2008-2009: análise do consumo alimentar pessoal no Brasil. Rio de Janeiro: IBGE [Internet]. 2011; [cited 2017 Feb 25]. Available from: http://biblioteca. ibge.gov.br/visualizacao/livros/liv50063.pdf

27. Silveira JAC, Colugnati FAB, Cocetti M, Taddei JAAC. Tendência secular e fatores associados ao excesso de peso entre préescolares brasileiros: PNSN-1989, PNDS-1996 e 2006/07. J Pediatr. 2014;90(3):258-66.

28. Jaime PC, Santos LMP. Transição nutricional e a organização do cuidado em alimentação e nutrição na Atenção Básica em saúde. Divulg Saúde Debate. 2014;51:72-85

29. Mello CS, Barros KV, Morais MB. Alimentação do lactente e do préescolar brasileiro: revisão da literatura. J Pediatr. 2016;92(5):451-63.

30. Santos CC, Stuchi RAG, Arreguy-Sena C, Pinto NAVD. A influência da televisão nos hábitos, costumes e comportamento alimentar. Cogitare Enferm. 2012;17(1):65-71.

31. Ministério da Saúde (BR). Secretaria de Atenção à Saúde. Departamento de Atenção Básica. Guia Alimentar para a População Brasileira. Brasília: Ministério da Saúde [internet]. 2014; [cited 2017 Jan 17]; 156 p. Available from: http://bvsms.saude.gov.br/bvs/publicacoes/ guia_alimentar_populacao_brasileira_2ed.pdf

32. Anzman SL, Rollins BY, Birch LL. Parental influence on children's early eating environments and obesity risk: implications for prevention. Int $\mathrm{J}$ Obes (Lond). 2010;34(7):1116-24.

33. Draxten M, Fulkerson JA, Friend S, Flattum CF, Schow R. Parental role modeling of fruits and vegetables at meals and snacks is associated with children's adequate consumption. Appetite. 2014;78:1-7.

34. Marchi-Alves LM, Yagui CM, Rodrigues S, Mazzo A, Rangel EML, Girão FB. Obesidade infantil ontem e hoje: importância da avaliação antropométrica pelo enfermeiro. Esc Anna Nery. 2011;15(2):238-44. 